\title{
ANALISIS PENGENDALIAN PEMANFAATAN RUANG DI KOTA SALATIGA
}

\author{
Istianah Setyaningsih \\ Institut Ilmu Sosial dan Manajemen STIAMI \\ istianah@stiami.ac.id
}

\begin{abstract}
Abstrak. Salatiga merupakan salah satu kota yang berada dalam Kawasan Strategis Nasional Kedungsepur, dan memiliki potensi baik dari sumber daya alam dan sarana dan prasarana memberikan peluang bagi Kota Salatiga untuk tumbuh dan berkembang dan salah satunya dengan melaksanakan pembangunan. Tingkat pembangunan yang tinggi menjadikan Kota Salatiga mengalami permasalahan dalam hal pemanfaatan ruang, antara lain keterbatasan lahan yang mengakibtakan pembukaan lahan-lahan pertanian, pelanggaran antara rencana tata ruang dengan pemanfaatan ruang, dan lemahnya penegakan hukum terhadap pelanggaran yang terjadi.

Fokus dan tujuan penelitian ini adalah untuk mendiskripsikan dan menganalisis bagaimana implementasi pengendalian pemanfaatan ruang di Kota Salatiga. Selain itu juga untuk mendiskripsikan dan menganalisis faktor-faktor yang berkontribusi pada implementasi pengendalian pemanfaatan ruang. Teori yang digunakan dalam penelitian ini adalah administrasi publik, implementasi kebijakan, penataan ruang dan pengendalian pemanfaatan ruang. Penelitian ini menggunakan tipe penelitian kualitatif dengan menggunakan metode analisis domain, analisis taksonomi dan analisis overlay peta dalam melihat Implemtasi Pengendalian Pemanfaatan Ruang di Kota Salatiga. Responden yang digunakan antara lain Dinas Cipta Karya dan Ruang Kota Salatiga, Satuan Polisi Pamong Praja Kota Salatiga, dan masyarakat Kota Salatiga.

Hasil penelitian ini menjelaskan bahwa implementasi pengendalian pemanfaatan ruang di Kota Salatiga dilaksanakan dalam tahapan pengawasan dan penertiban. Namun dalam prosesnya implementasi mengalami kendala berkaitan sumberdaya manusia pelaksana, koordinasi antar instansi pelaksana, proses evaluasi pemanfaatan ruang, sosialisasi yang dilaksanakan instansi pelaksana, anggaran pelaksanaan pengendalian dan kurangnya partisipasi dari masyarakat. Hal ini menyebabkan pengendalian pemanfaatan ruang di Kota Salatiga belum berjalan dengan maksimal. Pengendalian pemanfaatan ruang dapat dimaksimalkan dengan cara mengikutsertakan masyarakat dalam kegiatan pengendalian pemanfaatan ruang, meningkatkan anggaran untuk kegiatan pengendalian, meningkatkan koordinasi antar instansi pelaksana, meningkatkan sosialisasi tentang pengendalian pemanfaatan ruang dan meningkatkan peran serta pihak swasta dan masyarakat.
\end{abstract}

Kata kunci : Implementasi, Penataan Ruang, Pengendalian Pemanfaatan Ruang.

Abstract. Salatiga is one of the cities that were in the area of nationally strategic Kedungsepur, and has potential of natural resources and infrastructure and facilities provide opportunities for Salatiga city to grow and evolve and one of them with carrying out development. High levels of development making Salatiga city get in trouble in terms of the use of space, among athor limited land which resulted in the opening of agricultural lamd the offense of between spatial plan from the utilization of space, and weal law enforcement againts violations.

The focus and purpose of the research is to describe and analyze how the implementastion controling the utilization space in Salatiga City.In addition to describe and analyze the factors that contribute to the implementation of controling the utilization space in Salatiga space. The theory used in this research is Public Administration, Public Implementation, and control of spatial use of space. This research uses qualitative research type by using doamin analysis method, analysis of the taxonomy and analysis of overlay map within view the implementation of controling the utilization space in Salatiga space. The respondent who used, among others Dinas Cipta Karya dan Ruang Kota Salatiga, Satuan Polisi Pamong Praja Kota Salatiga and the people of Salatiga city. 
Itianah Setyaningsih, Analisis Pengendalian Pemanfaatan Ruang Di Kota Salatiga...

The result of this research explains that the implementation of the control usage space in the Salatiga city is implemented in stages of monitoring and curbing. But in the process of implementation encountered obstacles related to managing human resources, implementing agencies coordination, process evaluation of utilization of space, the implementing agencies carried out socialization, budget execution control and the lackof participation from people of teh Salatiga city. This caused the control usage space in the Salatiga city not running optimally.

Implementation of the control usage space in the Salatiga city can be maximized by means of the control activities in society involve the utilization of space, increasing the budget for tha activity control, improve coordination of agencies implementing, improving socialization about controling the utilization of space and increase the involvement of private and the people of the Salatiga city,

Keyword : Implementation, Spatial Plan, Controling the use of the space.

\section{PENDAHULUAN}

Globalisasi yang terus berkembang hingga saat ini telah memberikan pengaruh yang cukup signifikan bagi Pemerintah Indonesia dimana banyak Kota/Kabupaten berusaha untuk melakukan perbaikan dalam segala bidang baik secara sosial maupun fisik. Hal yang paling sering dilakukan oleh suatu negara untuk maju adalah dengan melakukan pembangunan secara fisik, baik negara berkembang maupun negara maju akan berusaha melakukan pembangunan untuk meningkatkan taraf hidup masyarakatnya guna dapat bersaing dengan negara-negara lain dan tidak tergerus atau tertinggal dengan perkembangan globalisasi yang semakin cepat.

Kegiatan pembangunan di Indonesia mengalami perkembangan yang sangat signifikan sehingga mengharuskan Pemerintah untuk mengeluarkan kebijakan yang mengatur tentang pembangunan. Kebijakan yang dikeluarkan oleh pemerintah pusat yaitu UU no 25 tahun 2004 tentang Sistem Perencanaan Pembangunan Nasional, dimana dalam undang-undang tersebut mengatur agar setiap pembangunan yang dilakukan baik di tingkat pusat maupun daerah saling berkaitan dan terjadi konfigurasi.

Pembangunan yang terus dilakukan baik oleh pemerintah pusat maupun pemerintah daerah dalam upaya meningkatkan taraf hidup masyarakat selain memberikan dampak postif juga menimbulkan dampak negatif yang tidak bisa dilepas begitu saja. Pembangunan yang dilaksanakan tanpa memperhatikan daya dukung lingkungannya dan hanya mengejar kepentingan ekonomis maka akan memberikan dampak yang cukup besar bagi lingkungan mulai dari terjadinya polusi udara, degradasi lingkungan sebagai akibat dari pembangunan yang tidak berwawasan lingkungan, pencemaran air sebagai akibat dari hasil limbah industri, hingga pengambilan kekayaan alam secara berlebihan dari perut bumi.

Oleh sebab itu perencanaan pembangunan akan selalu bersinggungan dengan pemanfaatan ruang, dimana pembangunan dapat dilaksanakan dengan memanfaatkan ruang yang tersedia. Pelaksanaan pembangunan harus dapat bersinkronisasi dengan pemanfaatan ruang yang telah ditetapkan. Perencanaan tata ruang dapat dikatakan sebagai kebijakan yang dapat meminimalisir dampak negatif dari pembangunan, baik dalam pemanfaatan ruang hingga pengendalian pemanfaatan ruang tersebut. Pemanfaatan ruang perlu untuk dikendalikan, dimana Pengendalian pemanfaatan ruang akan menjadi suatu perangkat manajemen pengelolaan kota yang sangat diperlukan untuk memastikan bahwa perencanaan tata ruang dan pelaksanaan pemanfaatan tata ruang berlangsung sesuai dengan rencana yang telah disepakati dan ditentukan oleh Pemerintah. Adanya pengendalian pemanfaatan ruang maka dapat mengetahui serta sekaligus menghindarkan kemungkinan akan terjadinya ruang penyimpangan fungsi ruang yang tidak diinginkan dan terarah sesuai dengan apa yang telah ada dalam rencana tata ruang kota. Perencanaan tata ruang dan pengendalian tata 
ruang dapat dikatakan sebagai dua sisi mata uang, yang mana pengendalian pemanfaatan ruang dapat berjalan dengan efektif dan efisien apabila perencanaan tata ruang disusun dengan tujuan memenuhi kebutuhan masyarakat.

Berdasarkan uraian di atas penulis tertarik untuk mengetahui (1) Bagaimana Implementasi Pengendalian Pemanfaatan Ruang di Kota Salatiga? (2) Apa saja faktorfaktor yang berkontribusi pada Implementasi Pengendalian Pemanfaatan Ruang

\section{TINJAUAN PUSTAKA}

\section{Kebijakan Publik}

Thomas R Dye dalam Suwitri (2008) mengartikan kebijakan publik sebagai setiap pilihan pemerintah untuk melakukan atau tidak melakukan suatu tindakan. Kebijakan publik menurut Nugroho (2009) merupakan manajemen pencapaian tujuan nasional yang mudah untuk dipahami karena maknanya adalah hal-hal yang dikerjakan untuk mencapai tujuan nasional dan kebijakan publik mudah diukur karena ukurannya jelas yakni sejauh mana kemajuan pencapaian citacita sudah di tempuh. Proses kebijakan publik itu sendiri mencakup tiga unsur pokok yaitu perumusan/formulasi kebijakan publik, implementasi kebijakan publik dan evaluasi kebijakan publik. Berikut skema kebijakan publik menurut Riant Nugroho dalam Nugroho (2003)

\section{Implementasi Kebijakan}

Implementasi kebijakan dalam Nugroho (2009) dimaknai sebagai cara agar sebuah kebijakan dapat mencapai tujuannya. Proses mengimplementasikan kebijakan dapat dilaksanakan melalui dua pilihan langkah yaitu secara langsung mengimplementasikan dalam bentuk program atau melalui formulasi kebijakan derivat atau turunan dari kebijakan publik tersebut. Misi merupakan hal pertama yang melekat pada organisasi, dimana misi merupakan alasan organisasi tersebut ada. Visi melekat pada individu yang ada dalam organsiasi. Penjabaran dari visi merupakan strategi atau rencana, dimana strategi merupakan arah makna atau politik dari upaya pencapaian tujuan. Strategi-strategi yang kemudian dibentuk dalam kebijakankebijakan baik yang bersifat publik maupun non publik. Jadi, kebijakan publik dapat dikatakan sebagai keputusan politik, terhadap pilihan atas strategi.

\section{Penataan Ruang}

Menurut Tjahjati (Saputro, 2012) Penataan ruang dapat diartikan sebagai upaya mewujudkan tata ruang yang terencana, dengan memperhatikan keadaan lingkungan alam, lingkungan sosial interaksi antar lingkungan, tahapan dan pengelolaan pembangunan serta pembinaan kemampuan kelembagaan dan sumberdaya manusia yang ada dan tersedia dengan selalu melandaskan pada kesatuan wilayah dan ditujukan sebesarbesarnya pada kemakmuran. Tujuan penataan ruang adalah untuk menciptakan pemanfaatan ruang yang berkualitas dalam bentuk : (a) mewujudkan keterpaduan dalam penggunaan SDA dan sumber daya buatan dengan memperhatikan SDM ; (b) Meningkatkan pemanfaatan SDA dan sumberdaya buatan secara berdaya guna, berhasil guna dan teoat guna untuk meningkatakan kualitas SDM dan (c) Mewujudkan perlindungan fungsi ruang dan mencegah serta menanggulangi dampak negatif pembangunan

\section{Kerangka Berfikir}

Dari uraian teori yang telah dipaparkan, maka dapat disusun kerangka berfikir sebagai berikut pada gambar 1 .

\section{METODE PENELITIAN}

\section{Perspektif Pendekatan Penelitian}

Pada tesis Analisis Implementasi Pengendalian Pemanfaatan Ruang di Kota Salatiga, peneliti memilih menggunakan penelitian kualitatif bersifat deskriptif, yaitu data yang terkumpul berbentuk kata-kata, gambar bukan angka-angka. Kalaupun ada angka-angka sifatnya hanya sebagai penunjang. Data yang diperoleh meliputi transkip interview, catatan lapangan, foto, 
Itianah Setyaningsih, Analisis Pengendalian Pemanfaatan Ruang Di Kota Salatiga...

dokumen pribadi dan lain-lain ( Danim, 2002:51).

Penelitian kualitatif bertitik tolak dari fenomenologis atau fenomena sosial dimana didasari oleh realita internal dan kebenaran merupakan hasil persetujuan, yang sesuai dengan kondisi sosial dan sejarahnya.

Gambar 1.

Skema Kerangka Berfikir

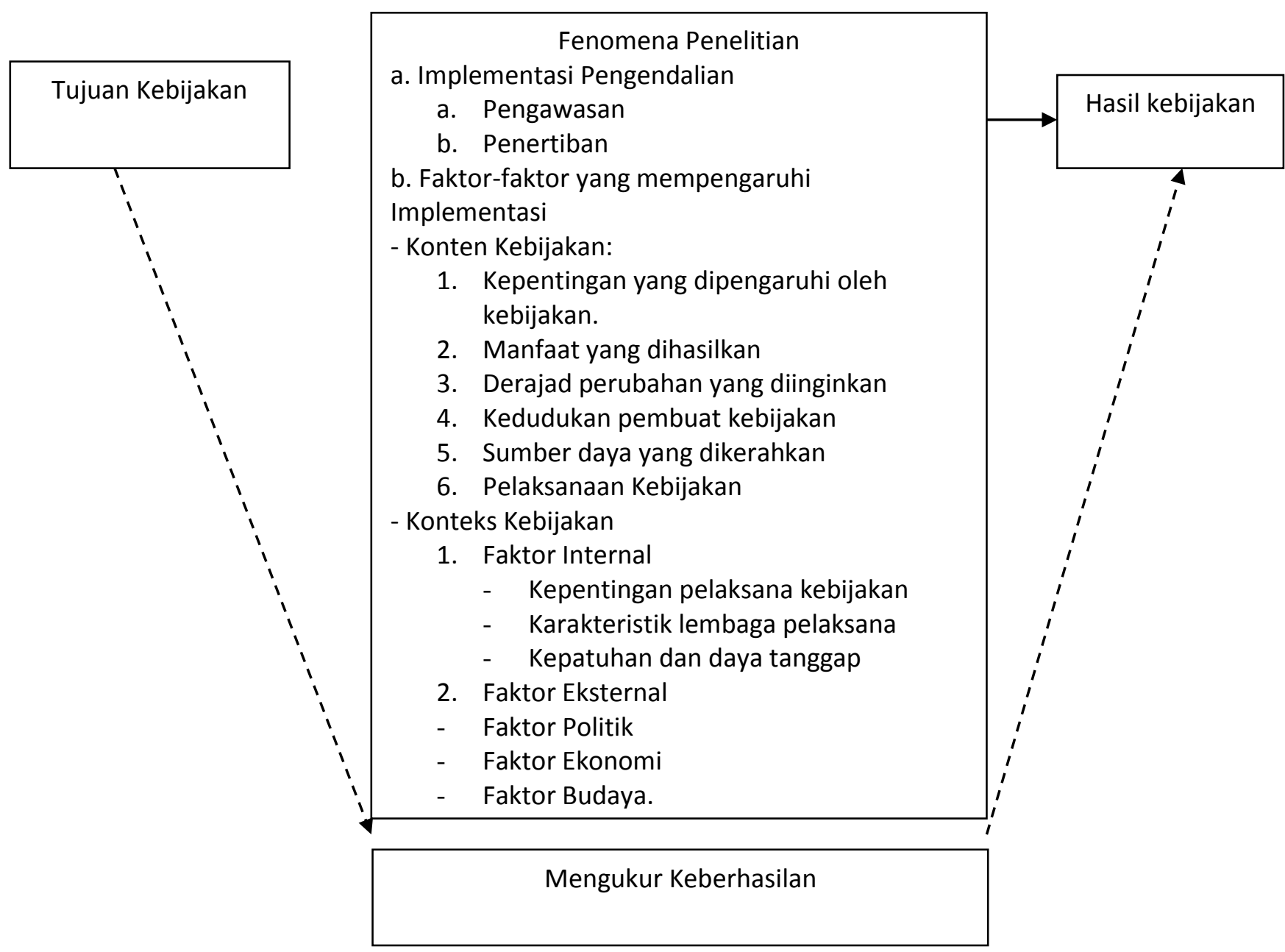

\section{Fokus Penelitian}

Fokus penelitian ini adalah mengenai Implementasi Pengendalian Pemanfaatan Ruang di Kota Salatiga sebagai upaya dari Pemerintah Kota Salatiga dalam rangka mengendalikan proses pembangunan agar sesuai dengan Rencana Tata Ruang dan Wilayah Kota.

\section{Lokasi Penelitian}

Penelitian ini mengambil lokus pada Badan Perencanaan Pembangunan Daerah Kota Salatiga yang beralamat di Jl. Letjend Sukowati No.51 Salatiga, Dinas Cipta Karya dan Ruang Kota Salatiga, dan Satuan Polisi Pamong Praja. Bappeda sebagai instansi pembuat aturan pengendalian sedangkan Dinas Cipta Karya dan Tata Ruang, dan Satuan Polisi Pamong Praja sebagai instansi pelaksana pengendalian pemanfaatan ruang.

\section{Jenis dan Sumber Data}

\section{a. Jenis Data}

Jenis data yang digunakan dalam penelitian ini adalah data berupa teks, katakata tertulis atau simbol-simbol yang menggambarkan atau merepresentasikan 
Jurnal Ilmiah Untuk Mewujudkan Masyarakat Madani

ISSN 2355-309X

orang-orang, tindakan-tindakan dan peristiwaperistiwa dalam kehidupan sosial.

\section{b. Sumber Data}

Berkaitan dengan hal itu, menurut sumbernya data yang digunakan dalam penelitian ini dibedakan menjadi dua, yaitu :

1. Data primer

Yaitu data yang diperoleh/diambil langsung dari sumbernya (subyek penelitian), yaitu informan dari Bappeda Kota Salatiga, Dinas Cipta Karya dan Ruang Kota Salatiga, serta Satuan Polisi Pamong Praja Kota Salatiga.

2. Data sekunder

Yaitu data yang diperoleh dari bahan kepustakaan yang relevan dengan permasalahan yang diteliti. Bentuk dari data sekunder ini bisa berupa catatancatatan, buku-buku litelatur, koran, dokumen, laporan, dan sumber-sumber lain yang berhubungan dengan penelitian.

\section{Pemilihan Informan}

Informan penelitian dalam penelitian ini merupakan individu atau kelompok yang mengetahui tentang persoalan yang sedang diteliti dan diharapkan memberikan informasi yang berkaitan dengan persoalan tersebut. Informan dipilih dengan teknik purposive sampling yaitu berdasarkan atas pertimbangan dan tujuan teretntu. Berikut adalah informan-informan yang dipilih dalam penelitian ini yang terbagi menjadi informan utama dan informan triagulasi :

1. Informan utama

Instansi Pelaksana pengendalian yaitu Dinas Ciptakaru dan Satuan Polisi Pamong Praja.

2. Informan Triangulasi

a. Instansi yang menjadi anggota BKPRD

b. Masyarakat.

\section{Instrumen Penelitian}

Dalam hal ini peneliti menggunakan interview giude ( pedoman wawancara) yang dibuat sebelum peneliti terjun ke lapangan, menyiapkan beberapa pertanyaan dan jawaban.

\section{Teknik Pengumpulan Data}

Teknik pengumpulan data yang digunakan dalam penelitian ini adalah:

1) Pengamatan atau observasi

Peneliti menggunakan observasi terus terang dan tersamar yaitu peneliti dalam melakukan pengumpulan data menyatakan secara terus terang kepada sumber data, bahwa ia sedang melakukan penelitian.

2) Wawancara

Peneliti menggunakan wawancara semitersturktur dimana peneliti dapat lebih bebas melakukan wawancara dan wawancara terstruktur dimana peneliti tetap menggunan interview guide (pedoman wawancara) yang dibuat sebelum peneliti terjun ke lapangan, menyiapkan beberapa pertanyaan dan jawaban.

3) Dokumentasi

Metode dokumentasi yaitu data yang diperoleh peneliti dari dokumen-dokumen yang berkaitan dengan objek penelitaian yang dapat diperoleh dari peraturan perundangundangan dan laporan dari instansi terkait.

4) Studi kepustakaan

Studi kepustakaan yaitu pengumpulan data dari buku-buku, internet, majalah, tulisantulisan serta referensi lain yang relevan dengan tujuan penelitian.

\section{Teknis Analisis Data}

Penelitian ini menggunakan teknik analisis data kualitatif, yaitu :

a. Teknik Analisa Domain

Teknik ini digunakan dalam penelitian untuk menganalisis gambaran objek penelitian secara umum, namun relatif diambarkan secara utuh tentang obyek penelitian tersebut (Sugiyono, 2012:110).

b. Teknik Analisa Taksonomi

Teknik analisis didasarkan pada fokus terhadap salah satu domain (struktur internal domain) dan pengumpulan hal-hal atau elemen yang sama (Sugiyono,2012:110). Analisis Taksonomi dilakukan setelah analisis domain, yaitu melakukan analisis terhadap keseluruhan data didasarkan pada pengelompokkan 
Itianah Setyaningsih, Analisis Pengendalian Pemanfaatan Ruang Di Kota Salatiga...

tertentu sebagaimana kategorisasi yang sudah didomainkan. Analisis taksonomi dapat dilakukan dengan membuat diagram, skema, outline dan cover term. Sedangkan teknik analisis taksonomi digunakan untuk menemukan hasil penelitian yang berkaitan dengan domain implementasi pengendalian pemanfaatan ruang berdasarkan Teori Grindle.

c. Teknik Perbandingan Peta

Teknik analisis perbandingan peta, yaitu teknik analisis yang merupakan pendekatan tata guna lahan/landscape. Analisis ini dimaksudkan melihat deskripsi kegiatan ekonomi yang potensial berdasarkan kriteria pertumbuhan dan kriteria kontribusi (Ahmad Haris). Teknik analisis perbandingan dilakukan dengan menggabungkan 2 atau lebih peta yang berfungsi untuk mencari peta analisis dengan melihat dari peta jenis tanah, kelerengan dan curah hujan untuk mengetahui fungsi kawasan pada wilayah/daerah tersebut.

\section{HASIL PENELITIAN}

Penelitian ini memiliki 5 orang informan dalam melakukan wawancara (interview) untuk mendapatkan data yang dibutuhkan oleh peneliti. Informan dalam penelitian ini terdiri dari Kepala Seksi Pengendalian Tata Ruang dan Bagunan Dinas Tata Kota Salatiga, Satuan Polisi Pamong Praja dan Masyarakat. Untuk selengkapnya daftar informan sebagai sumber data penelitian ini adalah sebagai berikut :

\section{Tabel Daftar Informan}

\begin{tabular}{|l|l|l|l|}
\hline No & Nama & Jabatan & Keterangan \\
\hline 1. & Roy Anjar, S.ST & $\begin{array}{l}\text { Kepala Seksi Bidang Pengendalian } \\
\text { Pemanfaatan Ruang dan Bangunan } \\
\text { Dinas Cipta Karya dan Tata Ruang }\end{array}$ & $\begin{array}{l}\text { Sekretaris Pokja Pengendalian } \\
\text { BKPRD }\end{array}$ \\
\hline 2. & Suharyono, SH & $\begin{array}{l}\text { Staf Bidang Penertiban dan Penegakan } \\
\text { Peraturan Daerah Satpol PP Kota } \\
\text { Salatiga }\end{array}$ & Pelaksana penertiban di Satpol PP \\
\hline 3 & Ibu Enny & Staf Satuan Polisi Pamong Praja & Pelaksana Penertiban di Satpol PP \\
\hline 4 & Bapak Ari & Ketua RW Kalicacing & Masyarakat \\
\hline 5 & Bapak Priambodo & Ketua RW Mangunsari & Masyarakat \\
\hline
\end{tabular}

\section{Data Hasil Wawancara pada informan tentang Implementasi Pengendalian Pemanfaatan Ruang.}

\section{Konten / Isi Kebijakan Pengendalian Pemanfaatan Ruang Kota Salatiga :}

\section{Kepentingan yang terpengaruhi dalam Implementasi Pengendalian Pemanfaatan Ruang.}

Pada sub bagian kepentingan yang terpengaruhi memiliki maksud adanya pihakpihak yang terpengaruh secara langsung dengan adanya pengendalian pemanfaatan ruang. Kepentingan yang terpengaruhi dalam Implemenatasi Pengendalian Pemanfaatan ruang terdiri dari beberapa pihak. Hal tersebut peneliti peroleh berdasarkan hasil wawancara berikut ini :
“ Kepentingan pihak-pihak yang terpengaruhi dengan adanya pengendalian pemanfaatan ruang ini bisa dilihat dari beberapa sisi mbak. Pihak pemerintah, pihak swasta dan masyarakat. Masing-masing terpengaruhi, pemerintah dari sisi pelaksanaanya harus bisa mewujudakan ruang sesuai dengan yang sudah direncanakan, swasta dari sisi ketika nanti mengajukan perijinan usaha harus menuruti peraturannya, dan masyarakat berkaitan dengan perijinan pembangunan rumah tinggal"'( Sumber : Roy Anjar, wawancara tanggal 27 Nopember 2013).

Berdasarkan hasil wawancara dengan informan tersebut dapat disimpulkan bahwa pihak yang terpengaruhi dengan adanya pelaksanaan pengendalian pemanfaatan ruang 
terdiri dari 3 (tiga) pihak, yaitu pemerintah, swasta dan masyarakat.

\section{Manfaat implementasi pengendalian pemanfaatan ruang}

Implementasi pengendalian pemanfaatan ruang memberikan manfaat yang sangat besar terutama berkaitan dengan penyesuaian antara rencana tata ruang wilayah dengan pemanfaatan ruang. Hal tersebut dapat dilihat dari wawancara yang dilakukan pada informan sebagai berikut :

"Adanya pengendalian pemanfaatan ruang memberikan manfaat yang cukup banyak. Terutama dengan adanya pengendalian maka akan ada penyesuaian antara rencana tata ruang wilayah dengan pemanfaatan ruang. Selain itu adanya pengendalian juga akan memberikan kontribusi besar terutama berkaitan dengan perijinan yang nantinya akan dikeluarkan. Terus kalau ada pengendalian kan nantinya pembangunan lebih bisa diatur mbak, masyarakat jadi ndak seenaknya membangun mbak. Kalau sekarang untuk manfaat ya meskipun belum terlalu maksimal tapi masih bisa dibilang lumayang mbak, karena sudah mulai sedikit tertata sperti di Pnacasila, di Sayangan walaupun belum maksimal mbak." (Sumber : Roy Anjar, wawancara tanggal 27 Nopember 2013)

Senada dengan hal diatas, masyarakat yang peneliti temui di lapangan juga mengatakan hal yang sama, berikut hasil wawancara tersebut

"Manfaatnya itu ya penting sekali mbak, kalau ada pengendalian pastikan lebih terawasi pemanfaatan ruangnya. Misal kayak tanah-tanah persawahan itu tidak akan lagsung berubah jadi pemukiman. Jadi kalau ada pengendalian itu bisa mengontrol supaya lahan-lahan hijau atau persawahan itu tidak dirubah jadi pemukiman. Kan bahaya buat kedepannya mbak. Juga buat rumah-rumah di pemukiman-pemukiman padat itukan kalau tidak dikendalikan nantinya makin sumpek dan tidak nyaman tho mbak." ( Sumber : Bapak Ardi, 10 Desember 2013)

Menurut informan ke 3 yaitu Bapak Suharyono, SH selaku staf bidang penertiban dan penegakan hukum dan peraturan daerah menjelaskan tentang manfaat adanya pengendalian, antara lain sebagai berikut :

"Manfaat dari adanya pengendalian itu ada dua mbak, satu yaitu untuk penataan kota agar sesuai dengan rencana tata ruang wilayah yang ada. Supaya lingkungannya menjadi indah bersih dan nyaman. Yang kedua, manfaatnya itu jatuh ke PAD mbak, dengan adanya pengendaliankan secara otomatis masyarakat diarahkan untuk mengurus perijinan-perijinan yang berkaitan dengan misal Ijin Mendirikan Bangunan, ijin gangguan, ijin pemasangan reklame dan sebagainya. Nah dari perijinanperijinan itu nanti ada retribusi yang akan dibayarkan ke PAD Kota Salatiga mbak. " ( wawancara 12 Desember 2013)

Berdasarkan hasil wawancara diatas dari sisi instansi pelaksana pengendalian yaitu Dinas Ciptakaru menyatakan dengan adanya pengendalian pemanfaatan ruang memberikan manfaat yang cukup besar, dimana adanya pengendalian akan terjadi kesesuaian antara rencana tata ruang dengan pemanfaatan ruang.

\section{Derajad perubahan}

Derajad perubahan yang dihasilkan dari Implementasi Pengendalian Pemanfaatan Ruang Kota Salatiga terdiri dari beberapa aspek. Hal tersebut dapat dilihat dari hasil wawancara yang dilakukan pada informan sebagai berikut :

" Adanya pengendalian pemanfaatan ruang tentu saja memberikan perubahan yang cukup besar mbak. Dilihat dari beberapa aspek, misalkan dari aspek keindahan kota, kota menjadi lebih tertata, lebih indah dan lebih nyaman. Sedangkan dilihat dari aspek kualitas tanah, dengan adanya pengendalian 
Itianah Setyaningsih, Analisis Pengendalian Pemanfaatan Ruang Di Kota Salatiga...

pemanfaatan ruang maka setiap masyarakat yang akan memanfaatlkan ruang harus mengikuti rencana tata ruang wilayah. Hal ini disebabkan tata ruang dari waktu ke waktu bukan semakin berkurang namun semakian bertambah. Katakanlah tanah $1000 \mathrm{~m}^{2}$ itu setiap hari dipergunakan, kalau tidak dikendalikan nantinya akan jadi bangunan semua kalau sudah menjadi daerah terbangun secara otomatis untuk tanah resapan berkurang. Akibatnya kan nanti ke ketersediaan air di permukaan dan air di bawah tanah mbak. Kedua, seberapa besarpun drainase kota di bangun oleh pemerintah, kalau pemanfaatan ruangnya tidak dikendalikan ya tidak akan cukup menampung limbah dari seluruh kota. Karena itu mbak dengan adaya pengendalian nantinya setiap pemanfaatan ruang harus membuat sumur resapan juga. Hal tersebut akan berpengaruh terhadap resapan air tanah maupun air permukaan.Ya itu harapan kedepannya mbak, kalau saat ini memang pengendalian belum memberikan perubahan yang maksimal mbak. Karena memang masih ada keterbatasan baik dalam SDM, keuangan dan pelaksanaan di lapangan mbak." (Sumber : Roy Anjar, wawancara tanggal 27 Nopember 2013)

Berdasarkan hasil wawancara tersebut, derajad perubahan yang diharapkan dengan adanya pengendalian pemanfaatan ruang dapat dilihat dari beberapa aspek, yaitu aspek keindahan kota, aspek kualitas tanah dan aspek drainase. Perubahan dilihat dari aspek keindahan kota, kota menjadi semakin tertata, indah dan nyaman. Perubahan dari aspek kualitas tanah, dengan adanya pengendalian pemanfaatan ruang masyarakat akan diarahkan untuk membangun sesuai dengan tata ruang.

\section{Kedudukan pembuat kebijakan}

Penanggungjawab utama adalah Walikota Salatiga sedangkan penanggungjawab dalam pelaksanaan pengendalian pemanfaatan ruang ada di sebuah badan yang dibentuk berdasarkan Perwal No.15 Tahun 2006
Tentang Badan Koordinasi Penataan Ruang Daerah ( BKPRD) Kota Salatiga. Hal tersebut dapat dilihat dari hasil wawancara yang dilakukan pada informan sebaai berikut:

“ Kebijakan besarnya tentang pengendalian itu ada di Perda NO 4 Tahun 2011 tentang RTRW Kota Salatiga dan yang bertanggungjawab Walikota. Sedangkan untuk yang bertanggungjawab dalam pelaksanaannya itu dibentuk suatu badan yaitu Badan Koordinasi Penataan Ruang Daerah sesuai Perwal No 15 Tahun 2006 tentang BKPRD Kota Salatiga. Anggota $B K P R D$ sendiri itu terdiri dari seluruh instansi dan SKPD Kota Salatiga, seluruh kecamtan dan kelurahan Kota Salatiga. Dalam BKPRD itu terbagi dalam dua pokja (program kerja), yaitu Pokja Perencanaan dan Pokja Pengendalian. Untuk pokja perencanaan yang bertanggungjawab Kepala Bidang Saprastaru Bappeda Kota, sedangkan untuk Pokja Pengendalian yang bertanggungjawab adalah Kepala Bidang Tata Ruang dan Bangunan pada Dinas Tata Kota. Sedangkan untuk yang bertanggungjawab di lapangan itu berbeda lagi, untuk pengendalian yang berbentuk pengawasan teruatama berkaitan dengan usaha itu tanggungjawab Dinas Tata Kota subbidang pengendalian, untuk pengendalian berbentuk pengawasan terutama berkaiatan dengan pemanfatan ruang pribadai menjadi tanggungjawab Perijinan Terpadu Kotas Salatiga, dan untuk pengendalian berbentuk penertiban itu merupakan tanggungjawab Satuan Polisi Pamong Praja Kota Salatiga" ( Roy Anjar, wawancara tanggal 27 November 2013).

Berdasarkan hasil wawancara diatas menyatakan bahwa dalam penanggungjawab utama adalah Walikota sedangkan pelaksanaan pengendalian pemanfaatan ruang, instansi yang bertanggungjawab merupakan badan yang dibentuk berdasarkan Perwal No 15 Tahun 2006 tentang Badan Koordinasi Penataan Ruang Daerah Kota Salatiga. 
Anggota BKPRD terdiri dari seluruh instansi dan SKPD Kota Salatiga, seluruh kecamatan dan kelurahan yang ada di Kota Salatiga.

\section{Sumber daya manusia}

Sumberdaya manusia pelaksana pengendalian terbagi dalam instansi-instansi pengendalian. Hal ini sesuai dengan hasil wawancara terhadap informan sebaga berikut :

"Sumberdaya manusia yang ada di Dinas Tata Kota khususnya subbidang pengendalian itu hanya ada 1 orang saja mba. Padahal wilayah yang harus dilakukan pengawasan untuk Kota Salatiga ada 4 kecamatan. Jadi kalau kami harus melakukan pengawasan setiap hari itu jelas tidak mungkin. Jadi ya untuk pelaksanaan pengendaliannya masih sangat terbatas. Walaoupun ada BKPRD tapi untuk SDM yang melaksanakan pengendalian ya hanya Dinas Tata Kota dan Satpol PP mbak."( Sumber : Roy Anjar, wawancara pada tanggal 27 November).

Berdasarkan hasil keterangan dari informan diatas diketahui bahwa sumberdaya manusia yang ada di Dinas Ciptakaru yang melaksanakan pengendalian pemanfaatan ruang jumlahnya terbatas.

Hal berbeda disampaikan oleh Bapak Suharyono, SH dari Satuan Polisi Pamong Praja :

" Di satpol pp sendiri mbak, sebenarnya secara kuantitas SDM pelaksana penertiban di lapangan itu mencukupi. Namun secara kualitas sangat kekurangan, kan kita hubungannya dengan penegakan perda mbak. Nah masyarakat sekarang itu sudah lebih kritis dan paham. Jadi ketika kami melakukan penertiban, masyarakat pasti akan menanyakan tentang aturannya sebenarnya seperti apa, sedangkan yang paham betul mengenai bidang hukum dan perundang-undangan itu sangat terbatas.Karena itu mbak, dari kami sering mengadakan kegiatan pembekalan untuk staf ataupun masyarakat mengenai hukum dan perundang-undangan yang berlaku mbak."( wawancara, 12 Desember2013)

Berdasarkan hasil wawancara diatas, SDM yang ada di Satuan Polisi Pamong Praja sebagai pelaksana penertiban secara kuantitas mencukupi akan tetapi secara kualitas masih sangat terbatas.

\section{Pelaksanaan pengendalian}

Pelaksana pengendalian pemanfaatan ruang terdiri dari beberapa subbidang antara lain sub bidang pelaksana, pengawasan dan penertiban. Hal ini disampaikan oleh Bapak Roy Anjar, berikut hasil wawancara tersebut : " Jadi mbak untuk pengendalian pemanfaatan ruang itu terbagi jadi dua, yaitu pengawasan dan penertiban. Kalau pengawasan itu di Dinas Ciptakaru sedangkan penertiban di Satpol PP" (wawancara 27 ovember 2013)

Hal senada disampaikan oleh Bapak Suharyono, SH dari Satpol PP

" Pengendalian itu ada dua mbak, pengawasan dan penertiban/penegakkan. Kalau pengawasan itu ada di Dinas Ciptakaru selaku SKPD yang membidangi, kemudian untuk penegakkannya masuk ke kita Satpol PP mbak." (wawancara 12 Desember 2013)

Berdasarkan hasil wawancara diatas, diperoleh informasi mengenai pelaksanaan penegndalian pemanfaatan ruang yang terbagi dalam dua jenis yaitu pengewasan dan penertiban/penegakkan. Pengawasan menjadi tanggungjawab Dinas Ciptakaru selaku SKPD yang membidangi dan penertiban atau penegakkan menjadi tanggungjawab Satpol PP.

\section{Instansi Pelaksana}


Itianah Setyaningsih, Analisis Pengendalian Pemanfaatan Ruang Di Kota Salatiga...

Pada sub bagian instansi pelaksana kebijakan pengendalian pemanfaatan ruang, peneliti menitikberatkan pada pembagian tugas dari masing-masing pelaksana yang ada dalam forum BKPRD, pengambil keputusan, koordinasi antar instansi pelaksana pengendalian.

\section{Pembagian tugas}

Pihak-pihak tersebut yang memiliki peran dalam terlaksananya pengendalian pemanfaatan ruang.

Keterangan mengenai hal tersebut peneliti peroleh dari hasil wawancara dengan Bapak Roy Anjar selaku sekretaris pokja pengendalian BKPRD sekaligus Kepala Bidang Pengendalian Dinas Ciptakaru, berikut hasil wawancara tersebut :

" Instansi pelaksana pengendalian itu ada di forum BKPRD mbak. BKPRD itu terbagi dua yaitu pokja perencaan dan pokya pengendalian. Nah di pokja itu sudah terbagi tugas dari masing-masing instansi yang jadi anggota.Koordinator untuk pokja pengendalian adalah Kepala Dinas Tata Kota Salatiga, sedangkan sekretarisnya adalah Kasubida Pengendalian Tata Ruang dan Bangunan DTK. Anggotanya seluruh kecamatan dan seluruh kelurahan, sedangkan SKPD terkait antara lain Bappeda, DPO, KPPT, Dishub, Satpol PP, bagian hukum dan bagian tata pemerintahan. Tapi untuk pelaksanaanya di lapangan ya Dinas Tata Kota dan Satpol PP mbak. Bentuk pengendaliannya sendiri itu terbagi jadi dua jenis mbak, yaitu pengawasan dan penertiban. Instansi pelaksana pengendalian yang berbentuk pengawasan itu adalah Subbidang Pengendalian Dinas Tata Kota, sedangkan untuk yang bentuknya penertiban instansi pelaksananya adalah Satuan Polisi Pamong Praja. Sedangkan anggota-amggota yang ada di BKPRD itu nanti fungsinya sebagai pemberi masukan tentang pengendalian yang biasanya bertemu lewat forum BKPRD setiap 3 bulan sekali mbak. Sedangkan untuk pembagian tugasnya nanti disesuaikan dengan jenis pengendaliannya mbak. Kalau berkaitan dengan pertanian maka akan diarahkan kepada Badan Pertanahan. Kalau berkaitan dengan informasi jaringan seperti pembangunan tower akan diarahakan ke Dinas Perhubungan tapi tentu nantinya akan berkoordinasi dengan Dinas Tata Kota lalu dikaitkan dengan kaidah tata ruang. Sistematika pengendalian dilakukan dengan pengisian form $F 1$ di kelurahan kemudian aparat kelurahan melakukan analisis dan rekapitulasi beberapa form 1 kedalam form F2. Pokja pengendalian di BKPRD Kab/Kota bertanggungjawab melakukan pengisisn form F3,F4, dan F5 Dan untuk F6, F7 dn F8 itu diisi oleh pokja pengendalian di BKPRD Provinsi mbak."

" Selain itu mbak, kita juga melibatkan masyarakat biasanya nanti masyarakat ikut memberikan aduan-aduan kalu memang ada pelanggaran mbak" ( Sumber : Roy Anjar, 27 November 2013)

Berdasarkan hasil wawancara diatas dapat disimpulkan bahwa, instasnsi pelaksana pengendalian pemanfaatan ruang diwadahi dalam satu forum yaitu Badan Koordinasi Penataan Ruang Daerah atau BKPRD. Masyarakat turut serta dilibatkan dalam pelaksanaan pengendalian pemanfaatan ruang, berbentuk pengaduan kepada Dinas Ciptakaru apabila menemukan pelanggaran pemanfaatan ruang baik yang bersifat pribadi maupun usaha.

\section{Pengambil Keputusan}

Pengambil keputusan dalam subbagian ini memiliki maksud instansi yang bertanggungjawab dalam pengambilan keputusan setiap tindakan yang diambil dalam pelaksanaan pengendalian pemanfaatan ruang. Hal tersebut dapat dilihat berdasarkan hasil wawancara berikut ini :

"Yang berwenang paling tinggi dalam mengambil keputusan itu ya walikota mbak nanti keputusannya disampaikan 
lewat BKPRD, cuma ketika sudah dilapangan untuk dilaksanakan pengendalian ya sudah beda lagi. Untuk yang berwenang mengambil keptusan dalam pengendalian seperti memberikan pertimbangan teknis, memberikan ijin boleh dilakukan pembangunan dengan syarat itu Dinas Tata Kota, sedangkan pengendalian yang seperti penertiban itu yang berwenang mengambil keputusan ya Satuan Polisi Pamong Praja. Nanti ada lagi mbak, setelah dapat diijin pertimbangan teknis dari Dinas Ciptakaru kan masyarakat harus melengkapi persyaratan pemanfaatan ruang yang tertera dalam surat. Kalau berkaitan pertanian ya ke BPN, kalau jaringan ya ke dishub. Jadi hampir semua instansi itu punya kewenangan dalam pengambilan keputusan tentang pengendalian, tapi disesuaikan dengan tanggungjawabnya masing-masing sesuai tugasnya." ( Sumber "Roy Anjar, 10 Desember 2013)

Berdasarkan hasil wawancara diatas informan menyatakan bahwa kewenangan tertinggi dalam mengambil keputusan berkaitan dengan penegndalian pemanfaatan ruang adalah Walikota, dimana keputusan walikota akan disampaikan kepada seluruh instansi melalui forum BKPRD.

\section{Koordinasi Tugas}

Koordinasi tugas dalam subbgain ini memiliki maksud kerjasama yang terjalin secara baik dengan tujuan untuk menghasilkan jumlah, waktu, dan arahan yang tepat dalam pelaksanaan tugas yang secara harmonis dan terpadu yaitu untuk melaksanakan pengendalian pemanfaatan ruang yang terpadu. Hal tersebut dapat dilihat dari hasil wawancara sebagai berikut:

" Koordinasi antara seluruh instansi pelaksana itu dilakukan lewat forum BKPRD yang memang setiap 3 bulan sekali diadakan pertemuan mbak. Dilaksanakan di Bappeda kota Salatiga, nah dalam forum itu setiap instansi mengajukan usulan maupun keluhan dalam proses pelaksanaan setiap tugasnya mbak.Nanti ada masukanmasukan dari anggota lalu kami tampung, kalau ada pelanggara nanti anggota memberikan ususlan lalu yang menindaklanjuti dilapangan itu kami dari Dinas Tata Kota mbak. Cuma ya koordinasinya masih belum bisa berjalan dengan lancar mbak, jadinya ya koordinasi belum bisa berjalan maksimal mbak. Kalau koordinasi dnegan satpol pp biasanya kita memberikan surat pemberitahuan kepada satpol kalau ada pelanggaran pemanfaatan ruang, sudang diberikan teguran dari Ciptakaru tapi belum ada etikat baik sehingga perlu dilakukan penegakkan. Selain itu kita $u=j u g a$ turt serta dalam penertiban mbak, tapi ya tetep leadingnya dari satpol" ( Sumber : Roy Anjar, 27 November 2013)

Berdasarkan hasil wawancara dengan Sekretariat Pokja Pengendalian BKPRD sekaligus Kepala Seksi Pengendalian Tata Ruang Dinas Ciptakaru tersebut, dapat ditarik kesimpulan bahwa koordinasi antar instansi pelaksana pengendalian pemanfaatan ruang dilaksanakan melalui forum BKPRD yang dilakukan setiap 3 bulan sekali. Namun forum tersebut belum berjalan dengan baik sehingga koordinasi belum mampu berjalan dengan maksimal.

\section{Pengawasan}

Pengendalian berbentuk pengawasan itu terdiri dari pengawasan pra pembangunan dan pasca pembangunan. Pengawasan dilaksanakan dalam bentuk pelaporan, pemantauan dan evaluasi. Hal tersebut peneliti peroleh dari hasil wawancara berikut ini :

" Pelaksanaan pengendalian yang bentuknya pengawasan itu ada 2 mbak, pengawasan pra pembangunan dan pengawsan pasca pembangunan. Pengawasan itu dilakukan dengan bentuk pelaporan dari pengguna, pemantauan dari kami, dan evaluasi. Pelaporan itu 
Itianah Setyaningsih, Analisis Pengendalian Pemanfaatan Ruang Di Kota Salatiga...

mbak yang jalan hanya pelaporan ketika mau membangun saja, setelah membangun itu harusnya lapor tapi masyarakat tidak pernah lapor. Pemantauan itu berjalan bersamaan ketika ada masyarakat yang lapor, lalu kami langsung melakukan pemantauan, sedangkan evaluasi itu belum jalan mbak. Pengawasan pra pembangunan itu dilakukan dengan cara melihat pengajuan perijinan dulu setelah itu kami melakukan survei lapangan bagaimana kondisi tempat yang akan dibangun itu. Kami berikan pengarahan tentang teknisnya jarak dari ruwas jalan, sumur resapan dan tinggi bangunan yang boleh di bangun baru nanti keluar ijinnya. Kalau untuk yang pengawasan pasca pembangunan itu kita lakukan kroscek lagi mb, kita periksa ijin-ijin yang sudah kita keluarkan lalu kita cek dilapangan sesuai atau tidaknya dengan ijin yang telah dikeluarkan. Untuk pengawasan sendiri tahun ini kita tidak terlalu banyak mbak, ya karena ada keterbatasan dana dan sumberdaya. Tahun lalu kami dapat dana khusus untuk monotoring dan evaluasi ya lumayan cukup besar, tapi tahun ini kami tidak ada dana khusus monev mbak.Jadi ya untuk pengawasan berjalan seadanya dana yang terbatas, jadi kurang maksimal. Selain itu juga rencana detail tata ruang juga belum ada mbak, jadinya ya belum bisa dilakukan pengawasan secara lebih detail." Selain itu juga kita lakukan pengawasan bangunan yang sudah ada mbak, bangunan itu dibangun dengan ada ijin atau tidak " (Roy Anjar, 27 November 2013).

Berdasarkan hasil wawancara diatas informan menyatakan pengawasan terdiri dari pengawasan pra pembangunan dan pasca pembangunan, yang dilakukan dalam bentuk pelaporan, pemantauan dan evaluasi. Pelaporan yang berjalan hanya pelaporan dari masyarakat yang akan melaksanakan pembangunan sedangkan pelaporan selama pembangunan dan sesudah terlaksana pembangunan tidak berjalan dengan maksimal.

Sedangkan kegiatan evaluasi belum berjalan hal tersebut dinyatakan oleh informan dalam wawancara berikut ini.

“ Selain pengawasan seharusnya DTK juga melakukan monitoring dan evaluasi mbak, yang berkaitan dengan pelaksanaan dari pembangunan. Hanya saja tahun 2013 ini kami tidak melakukan monev karena tidak ada anggaran yang khusu untuk monev mbak."( Roy Anjar, 27 November 2013).

Selama pengawasan menemukan adanya pelanggaran, maka yang dilakukan oleh Dinas Ciptakaru adalah sebagai berikut :

“ Kalau dalam proses pengawasan pra ataupun pasca terjadi pelanggaran yang kita temukan, nantinya pasti kita tindak mbak. Tapi tindakan dari Dinas CIptakaru itu hanya memberikan surat teguran ke pihak yang melanggar. Surat teguran itu kami berikan sampai 3 kali, setelah surat teguran ketiga datang tapi pihak yang melanggar belum melaksanakan arahan dari surat teguran itu ya berarti lanjut ketindakan selanjutnya yaitu penertiban. Selain itu mbak biasanya kalau sampai pihak pelanggaran menjalankan arahan surat teguran maka kalu nanti dia mangajukan ijin lagi ya ijinnya tidak bisa kami keluarkan mbak." ( Roy Anjar, 27 November 2013)

Berdasarkan hasil wawancara diatas, dapat disimpulkan bahwa pengendalian pemanfaatan ruang ketika sudah terjadi pelanggaran dilakukan dengan cara memberikan surat teguran kepada pihak pelanggar, surat teguran diberikan hingga 3 kali. Apabila setelah surat teguran ketiga disampaikan namun masyarakat belum melaksanakan arahan dari surat teguran tersebut maka tindakan selanjutnya adalah dilakukan penertiban. 
Selain menggunakan pengawasan, pelaksanaan pengendalian pemanfaatan ruang juga dilakukan melalui beberapa instrumen. Informasi ini peneliti peroleh dari hasil wawancara berikut ini “

\begin{abstract}
“ Sebenarnya untuk pelaksanaan pengendalian selain pengawasan juga dilakukan melalui instrumen pengendalian yang sudah ditetapkan di UU No 26 Tahun 2007 mbak. Instrumennya itu ada peraturan zonasi, insentuif dan disinsentif, dan perijinan. Tapi dari ketiga instrumen itu yang baru jalan ya perijinan itu mbak, baik perijinan seperti IMB, ijin gangguan dll. Tapi kalau untuk peraturan zonasi, insentif dan disinsentifnya belum dilaksanakan mbak,. Karena rencana detail tata ruang yang mengatur lebih rinci tentang instrumen-instrumeb belum ada mbak. “ (Sumber ; Roy Anjarm, 10 Desember 2013)
\end{abstract}

Berdasarkan hasil wawancara diatas dapat diperoleh informasi bahwa dalam pelaksanaan pengendalian pemanfaatan ruang selain dilaksanakan melalui mekanisme pengawasan juga dapat dilaksanakan dengan menggunakan instrumen-instrumen pengendalian yaitu peraturan zonasi, perijinan, insentif dan disinsentif. Namun dalam pelaksanaannya instrumen yang dapat dilaksanakan dalam pengendalian hanya perijinan, sedangkan instrumen lain seperti peraturan zonasi, insentif dan disinsentif belum dapat dilaksanakan karena Rencana Detail Tata Ruang yang mengatur secara lebih rinci tentang instrumen tersebut belum ada.

\section{Penertiban}

Pengendalian pemanfaatan ruang dalam bentuk penertiban dilakukan apabila telah terjadi pelanggaran. Berikut hasil wawancara dengan infroman ;

"Penertiban itu dilakukan setelah kami
memberikan surat teguran tapi
masyarakat tidak mengindahkan surat
teguran tersebut. Waktu pelaksanaannya itu tergantung dari Satpol PP mbak, DTK sudah tidak berwenang lagi. Kami sifatnya hanya memberitahukan kepada Satpol PP bahwa ada pelanggaran."

" Kalau untuk penertiban sebenarnya masih banyak kendalanya mbak, terutama untuk pelanggaran yang cukup besar, contohnya kami pernah menemukan pelanggaran tentang pembangunan tower yang tidak sesuai dengan peruntukan ruang. Tapi kami tidak bisa merobohkan towernya begitu saja mbak. Pertama karena itu harus memotong arus bertegangan tinggi, kedua dibutuhkan dana yang sangat besar untuk melakukan tindakan pemotongan arus tersebut, sedangkan dana yang ada itu sangat terbatas. Pada akhirnya ya kami hanya memberikan surat teguran dan dilakukan penyegelan bersama dnean Dinas Perhubungan" (Sumber : Roy Anjar, wawancara pada tanggal 27 November 2013).

Berdasarkan hasil wawancara diatas, bahwa pelaksanaan penertiban dilakukan oleh Satuan Polisi Pamong Praja, berkoordinasi dengan instansi-instasni terkait.

Hal senada disampaikan oleh Bapak Suharyono, $\mathrm{SH}$ :

“ Untuk pengendalian yang berbentuk penertiban adalah tanggungjawab kami dari Satpol PP mbak. Penertiban sendiri itu tidak hanya berkaitan dengan bangunan mbak, tetapi juga reklamereklame yang terpasang di kota mbak. Pelaksanaan penertiban sendiri itu tidak serta merta ketika ada pelanggaran langsung kita tertibkan mbak, Ada dua cara yang kita lakukan yaitu secara yustisi dan non yustisi. Non yustisi itu kita lakukan dengan tindakan-tindakan persuasif mbak. Misalkan ada pemohon reklame atau ijin pembangunan, mengajukan di satu titik yang menurut pemohon letaknya strategis namun ternyata tata ruangnya tidak memungkinkan maka titik itu tidak bis diijinkan. Pada saat pemohon datang 
Itianah Setyaningsih, Analisis Pengendalian Pemanfaatan Ruang Di Kota Salatiga...

melakukan permohonan untuk mendirikan papan reklame, dan kebetulan papan rekalme itu belum didirikan maka kita arahkan secara persuasif mbak. Kita arahkan berdasarkan ketentuan tata ruangnya, daerah mana saja yang boleh diijinkan atau tidak, si pemohon tinggal memilih daerah yang diingikan. Namun ketika pembangunan reklame itu sudah terjadi maka kita akan melakukan penertiba secara yustisi. Pembongkaran juga tidak langsung kita lakukan mbak, terlebih dahulu kota himbau, kita berikan teguran. Kalau dalam jangka waktu yang kita berikan namun masyarakat yang bersangkutan tidak memiliki etiket baik untuk membongkar sendiri maka baru kami lakukan pembongkaran dan barang bukti hasil pembongkaran akan kami bawa ke kantor mbak. Itu untuk pelanggaran reklame, sedangkan untuk pelanggaran bangunan kita bisa saja melakukan pembongkan apabilaa pelanggarannya sudah tidak sesuai dengan tata ruang. Sebagai contoh bangunan-bangunan yang ada di sepanjang ruwas jalan, itukan ada aturannya mbak. Berapa jaraknya dan sebagainya, pada saat terjadi pelanggaran seperti itu maka bangunan yag melanggar akan kita tertibkan dan bisa dilakukan pembongkaran" ( wawancara 12 Desember 2013)

Hal senada dituturkan oleh ibu Enny selaku staf di Satpol PP

"Penertibannya itu dilakukan dengan 2 pendekatan mbak.yaitu yustisi dan non yustisi. Kalo yang non ystisi itu persuasif mbak, sedangkan yang yustisi itu penegakan di lapangan. Tapi mbak ketika kita dilapangan itu kita menemukan bahwa masyarakat melanggar itu bukan karena mereka tahu dan sengaja melanggar, justru sebagian masyarakat itu tidak mengetahui bahwa ada ketentuan hukumnya seperti itu mbak. Karena ya itu mau perundangundangan ataupun perda ketika sudah disahkan dalam lembaran negara atau perda, semua masyarakat dianggap sudah tahu. Padahal secara aktual masyarakat betul-betul belum tahu. Jadi ketika kita melakukan operasi simpatik ataupun persuasif kita akan mengalah tidak langsung melakukan penertiban tapi kita sampaikan prinsip tentang bangunan ini sebenarnya belum memnuhi syarat, lalu kita berikan ketentuannya, aturannya kemudian juga tentang pengajuan perijinan. Itu jika dari sisi kita yang jemput bola, tapi dari masyarakat juga ada kontribusinya mbak. Banyak juga laporan dari masyarakat yang menyampaikan ke kami tentang masyarakat yang melakukan pelanggaran. Setelah adanya laporan lalu akan kami tindak lanjuti mbak. Presentase dari pelaopran masyarakat itu juga cukup besar mbak. Artinya masyarakat juga sudah memahami tentang ketentuan yang ada dan juga ikut berperan serta dalam upya menciptakan ketertiban umum dan ketentraman masyarakat" ( wawancara 12 Desember 2013)

Berdasarkan hasil wawancara tersebut, pelaksanaan pengendalian berupa penertiban dilakukan oleh Satuan Polisi Pamong Praja, dimana penertiban tidak hanya dilakukan pada bangunan tetapi juga dalam bentuk penertiban reklame-reklame. Penertiban dalam pelaksanaannya di lapangan dilakukan melalui 2 pendekatan yaitu pendekatan secara yustisi dan non yustisi. Pendekatan yustisi dilakukan dengan cara tindakan penertiban seperti pembongkaran, sedangkan tindakan non yustisi dilakukan secara persuasif seperti memberikan pengarahan tentang peraturan dan sosialisi di lapangan.

Sedangkan untuk pelaksanaan penertiban dilakukan dengan membentuk tim ketertiban kota yang berdasarkan pada SK Walikota. Hal tersebut disampaikan oleh Bapak Suharyono, $\mathrm{SH}$ :

"Penertiban itu kita lakukan dengan membentuk satu tim yaitu Tim Ketertiban Kota mbak, yang dibentuk bersadarkan SK Walikota. Disitu ada tim nya terdiri 
dari instansi-instasni terkait seperti Ciptakaru, Dinas Pasar, dinas pendapatan daerah. Koordinasinya kita lakukan dengan memberikan surat pemeritahuan kepada instansi-instasni tersebut bahwa akan diadakan operasioperasi penertiban mbak. Tim ini terlepas dari BKPRD mbak, karena tim ini dibentuk hanya sebagai eksekutor ketika terjadi pelanggaran" ( wawancara 12 Desember 2013)

Pelaksanaan penertiban dilaksanakan oleh Satpol PP dengan membentuk suatu tim yaitu Tim Ketertiban Kota yang dibentuk berdasarkan SK Walikota, dimana dalam tim tersebut terdiri dari instansi-instansi yang terkait seperti Ciptakaru, Dinas Pasar dan Dinas Pendapatan Daerah.

\section{Konteks Kebijakan Pengendalian Pemanfaatan Ruang ( Perda No 4 Tahun 2011 tentang Rencana Tata Ruang Wilayah Kota Salatiga)}

\section{Faktor Internal}

\section{Tingkat Kepatuhan dan daya tanggap}

Tingkat kepatuhan dan daya tanggap masyarakat dalam mematuhi kebijakan tentang pengendalian pemanfaatan ruang dilihat melalui perijinan yang diajukan oleh masyarakat. Hal tersebut sesuai dengan hasil wawancara sebagai berikut :

" Kalau dilihat dari masuknya perijinan yang masuk ke Dinas Tata Kota itu mbak, bisa dikatakan masyarakat cukup patuh. Karena volume perijinan yang masuk juga cukup banyak mbak, Tapikan sebenarnya tidak hanya bisa dilihat dari situ saja mbak, misalkan banyak masyarakat yang mengajukan IMB terus ada retribusi yang masuk ke PAD. PADNya cukup tinggi, karena PAD tinggi lalu dikatakan masyarakat patuh. Tidak bisa seperti itu mbak, lha kenyataannya masih saja banyak terjadi pelanggaran di lapangan. Kadang masyarakat itu kalau diberitahu tentang adanya pengendalian itu selalu beranggapan bahawa pemerintah itu mempersulit pembangunan. Padahal kenyataannya adanya pengendalian itu bangus untuk kehidupan kedepannya. Mungkin tidak untuk 5 tahun kedepan, tapi 10 tahun kedepan itu pasti sangat bermanfaat." (Sumber : Roy Anjar, 27 November 2013).

“ Itu kalau dari sisi masyarakatnya mbak, kalau dari sisi SKPD anggota BKPRD Pokja Pengendalian hampir semua instansi tahu dan paham betul dengan adanya pengendalian pemanfaatan ruang. Jadi ketika ada masyarakat datang untuk mengajukan perijinan misalnya ya instansi itu akan benar-benar melihat peraturan tata ruangnya, peraturan yang berkaitan dengan apa pemanfaatan ruang itu. Kalau pertanian yang berarti UU agraria mbak.lalu dari instansi itu saling kerjasama mbak, makanya bisa dikatakan bahwa instansi pelaksana iu sudah melaksanakan dengan baik." ( Sumber : Roy Anjar, 10 Desember 2013)

Tingkat kepatuhan dan daya tanggap dalam pelaksanaan pengendalian pemanfaatan ruang berdasarkan hasil wawancara terbagi dalam dua sisi, yaitu sisi masyarakat dan sisi instansi pelaksana yang berada di keanggotaan Pokja Pengendalian BKPRD.

Tanggapan masyarakat dapat juga dilihat dari kegiatan pengendalian yang berbentuk penertiban, berikut hasil wawancara yang berkaitan dengan daya tanggap masyarakat dalam penertiban :

"Tanggapan masyarakat ketika adanya penertiban itu sebenarnya cukup baik mbak, hanyas ja ya itu pemberitaan di media tentang sisi negatif dari Satpol PP. Padahal masyarakat ketika kami melakukan penertiban tidak serta merta langsung melakukan pembongkaran. Selalu ada jeda 1 atau 2 bulan, dnegan cara persuasif dulu. Baru setelah jatuh tempo itu kita lakukan pembongkaran. Saat kami melakukan tindakan persuasif di lapangan dengan memberikan penjelasan-penjelasn, masyarakat dapat 
Itianah Setyaningsih, Analisis Pengendalian Pemanfaatan Ruang Di Kota Salatiga...

menerima dan memahami jadi setelah jatuh tempo kami tidak harus melakukan pembongkaran paksa. Karena masyarakat sudah sadar dan membongkar bangunan mereka yang melanggar dengan sendirinya. Dan juga dari sering adanya laporan masyarakat kepada kita tentang adanya pelanggaran, itu juga merupakan tanggapan yang baik dari masyarakat untuk menciptakan kota yang nyaman dan tentram mbak." ( sumber : Pak Suharyono, SH, wawancara 12 Desember 2013)

Daya tanggap masyarakat terhadap pengendalian pemanfaatan ruang yang berbentuk penertiban sangat baik, dimana masyarakat melaksanakan keputusan dari hasil penertiban tanpa adanya pembongkaran paksa dari Satpol PP.

\section{Sosialisasi.}

Sosialisasi pada sub bagaian ini merupakan informasi yang diberikan oleh pihak instansi pelaksana kepada masyarakat mengenai peraturan-peraturan yang dikeluarkan oleh pemerintah.. Sosialisasi yang dilaksanakan dalam rangka pengendalian pemanfaatan ruang oleh Dinas Tata Kota adalah sebagai berikut :

"Sosialisasi kita lakukan mbak,yang bertanggungjwaba melaksanakan itu Dinas Tata Kota lalu biasanya kita koordinasi dengan kecamatan, Bappeda, SKPD terkait seperti Kantor Pertanahan, KPPT, dan lain-lain mbak. Sosialisasi kita lakukan kalau ada peraturan baru yang disahkan mbak. "( Sumber : Roy Anjar, 10 Desember 2013)

Sosialiasi kepada masyarakat dilakukan oleh Dinas Tata Kota sebagai penanggungjawab, dan berkoordinasi dengan kecamatan, kelurahan, Bappeda dan instansi yang terkait seperti KPPT, Kantor Pertanahan dan pihak lain. Sosialisasi dilakukan ketika adanya peraturan baru yang disahkan oleh pemerintah, dan salah satunya adalah Rencana Tata Ruang dan Wilayah Kota.
Namun kegiatan sosialisasi tentang pengendalian pemanfaatan ruang belum berjalan dengan maksimal. Hal ini disampaikan oleh masyarakat, berikut ini hasil waawancara :

" Kalau sosialisasi tentang RTRW di tingkat kecamatan itu memang ada mbak, tapi biasanya diadakannya tidak tentu waktunya. Kadang setahun sekali, kadang dua kali setahun, tapi ya itu mbak sosialisasinya itu cuma sampai kecamatan saja. Kami yang dimasyarakat lapisan bawah ndak pernah tahu itu ada pengendalianpengendalian. Padahal harusnya itu penting sekali mbak. Kan yang terlibat langsung dalam pemanfaatan itu masyarakat lapisan bawah tho mbak." ( Sumber : Pak Rudi, 10 Desember 2013)

Berdasarkan hasil wawancara terhadap masyarakat diatas, maka dapat dikatakan bahwa sosialisasi yang dilakukan oleh pemerintah berkaitan dengan Rencana Tata Ruang Kota Wilayah, dan sosialisasi tentang pengendalian belum berjalan secara maksimal. Sosialisasi hanya dilakukan hingga tingkat kecamatan, sedangkan masyarakat yang berada di tingkat bawah tidak memperoleh informasi apapun.

\section{Faktor Eksternal}

\section{Faktor Politik}

Faktor politik yang terdapat dalam implementasi pengendalian pemanfaatan ruang berbentuk dukungan dari pemerintah. Dukungan tersebut dapat dilihat dari hasil wawancara sebagai berikut :

"Bentuk dukungan secara politiknya itu mbak ya dibuatnya rencana detail tata ruang mbak, karena di rencana detail tata ruang itu instrumen lengkap tentang pengendalian akan diatur, seperti insetif dan disintensif, peraturan zonasi juga mbak.. Hanya saja dari sejak tahun 2010 RTRW disahkan sampai sekarang Rencana Detail Tata Ruangnya masih dalam proses di dewan ' (Sumber : Roy Anjar, 10 Desember 2013). 
Bentuk dukungan dari pemerintah kota secara politik adalah disusunya Rencana Detail Tata Ruang dan Wilayah Kota Salatiga yang didalamnya mengatur lebih detail tentang pengendalian serta memuat intrumenintrumen pengendalian seperti peraturan zonasi, insentif dan disinsentif. Namun hingga tahun 2013 Rencana Detail Tata Ruang masih dalam proses pembuatan.

Faktor politik lain yang juga mempengaruhi adalah terjalinnya koordinasi dari masingmasing instansi pelaksanaan dalam hal memberikan perijinan pemanfaatan ruang kepada masyarakat. Hal ini disampaikan oleh Bapak Suharyono, SH dari Satpol PP

" Dukungan poliik bentuknya juga bisa adanya koordinasi antar instansi yang menjadi pelaksana mbak. Dimana antar instansi itu saling bekerjasama dalam wadah BKPRD, lalu dalam Tim Ketertiban Kota yang semuanya terbentuk karena adanya Peraturan Walikota dan SK Walikota mbak."( Sumber ; Pak Suharyono, SH. 12 Desember 2013)

Dukungan politik dari pemerintah kota salah satunya adalah dibentuknya forum BKPRD sebagai wadah penataan ruang daerah dan Tim Ketertiban Kota sebagai eksekutor penertiban pelanggaran., dimana wadah tersebut dibentu berdasarkan Peraturan Walikota dan Surat keputusan Walikota. Selain itu bentuk dukungan lain yang diberikan pemerintah adalah berkaitan dengan anggaran. Informasi tersebut peneliti peroleh dari wawancara dengan informan, berikut hasil wawancara tersebut :

“ bentuknya dukungan mbak dari pemerintah kota, dukungannya berupa anggaran baik untuk Dinas Tata Kota maupun Satpol PP. Hanya saja anggaran yang ada tahun ini itu cuma anggaran untuk sosialisasi, panggung reklame yang dipasang khusus untuk pelaku usaha supaya tidak memasang reklame sembarangan. Sedangkan anggaran untuk pengendalian itu ada tapi kecil mbak, lha kalau kami mau mengajukan anggaran yang cukup besar tapi staf pengendalian saja hanya ada 1 orang nanti tidak masuk akal mbak. Padahal yang dilapangan anggarannya masih sangat kurang mbak." ( Sumber : Roy Anjar, 27 November 2013)

Bentuk dukungan secara politik yang lain dari pemerintah dalam pelaksanaan pengendalian pemanfaatan ruang adalah dengan adanya anggaran yang khusus dialokasikan untuk pelaksanaan pengendalian. Namun anggaran yang ada saat ini baru anggaran untuk kegiatan pengendalian yaitu sosialisasi dan poenyediaan panggung reklame. Sedangkan anggaran untuk kegiatan pengendalian seperti monitoring dan evaluasi tidak ada.

Hal senada disampaikan oleh Bapak Suahryono, SH dari satuan polisi pamong praja mengenai dukungan yang diberikan oleh pemerintah kota ;

"Adanya anggaran untu setiap kegiatan itu merupkan bentuk dukungannya mbak. Anggaran yang kita terima ya kalu dituruti sebneranya tidak mencukupi, tapai bagaimanapun kita harus menggunakan anggaran tersebut secara efektif dan efisien mungkin" ( wawancara, 12 Desember 2013)

Anggaran dialokasikan oleh pemeriintah kota sebagai bentuk dukungan, dimana anggaran yang ada di Satpol PP pada dasarnya tidak mencukupi. Namun Satpol PP menggunakan anggaran tersebut secara efektif dan efisien, sesuai dengan kegiatan yang direncanakan.

\section{Masyarakat}

Peneliti melakukan penelitian terhadap 2 informan untuk mengetahui seberapa besar peran serta masyarakat dalam pelaksanaan pengendalian pemanfaatan ruang.

Berikut hasil wawancara dengan informan pertama :

" kami tahu mbak kalau tentang peraturan-peraturan pengendalian tata 
Itianah Setyaningsih, Analisis Pengendalian Pemanfaatan Ruang Di Kota Salatiga...

ruang. Kalau mau mengajukan perijinan yang harus dapat surat rekomendasi dari $R T / R W$, kelurahan, kecamatan lalu ke Dinas Tata Kota dulu. Cuma ya itu mbak prosesnya ribet, jadinya terkadang malas mengurus" ( Sumber :, Pak Pri. 10 Desember 2013)

Hal berbeda disampaikan oleh informan ke 2 , berikut hasil wawancara :

" kita ndak tahu mbak kalau memang ada pengendalian-pengendalian githu. Ya tahunya cuma mengajukan ijin mau membangun, tapi kalau harus melapor saat bangun, ataupun setelah bangun ya ndak tahu mbak.Kalau ijin udah keluar ya kami mikirnya sudah selesai." ( Sumber: Masyarakat ke 2, Pak Ardi, 10 Desember 2013)

Partisipasi masyarakat dalam pengendalian dapat dilaksanakan dengan melaporkan kepada instansi terkait jika melihat terjadinya pelanggaran pemanfaatan ruang.

\section{Informan pertama}

" Iya mbak, kami dari masyarakat bisa berpartisipasi dalam kegiatan pengendalian. Contohnya mbak ketika ada yang membangun dan itu jelas melanggar sempadan jalan ya kita langsung lapor ke Dinas Tata Kota. Kalau untuk langsung menegur kita tidak bisa mbak, kan tidak punya wewenang seperti itu. Tapi ya itu mbak, setelah melapor kadang responnya cepat kadang juga lambat."( Sumber : Pak Pri. 10 Desember 2013)

Hal berbeda disampaikan oleh masyarakat informan ke 2

"Ya tahu mbak, tapikan kami tidak mau repot. Ngapain melaporkan orang lain, yang penting kegiatan membangunanya mereka itu tidak menganggu kami." ( Sumber : Masyarakat ke 2, Pak Ardi, 10 Desember 2013)

Berdasarkan hasil wawancara diatas dapat dikatakan bahwa ada masyarakat yang peduli dengan lingkungannya dan ikut berpartisipasi dalam proses pengendalian ketika melihat terjadinya pelanggaran. Namun ada pula masyarakat yang ketika melihat terjadinya pelanggaran tidak peduli dan memilih membiarkannya.

\section{PEMBAHASAN HASIL PENELITIAN}

\section{Konten Kebijakan Pegendalian Pemanfaatan Ruang Kota Salatiga. \\ Kepentingan yang terpengaruhi dalam Implementasi Pengendalian Pemanfaatan.}

Implementasi kebijakan, dalam
prosesnya di lapangan akan selalu mempengaruhi berbagai pihak yang berkaitan tentang kebijakan tersebut, dimana pengaruh tersebut merupakan hasil dari pelaksanaan kebijakan tersebut. Implementasi Pengendalian Pemanfaatan Ruang di Kota Salatiga, dalam pelaksanaannya mempengaruhi berbagai pihak, baik pihak yang dipengaruhi secara langsung maupun tidak langsung.

Melalui wawancara yang telah peneliti lakukan dengan informan, dapat ditarik kesimpulan bahwa dalam Implementasi Pengendalian Pemanfaatan Ruang Kota ada beberapa pihak yang terpengaruhi, diantaranya adalah pemerintah, swasta dan masyarakat. Pemerintah terpengaruhi dalam kaitanya sebagai pelaksana kebijakan pengendalian harus mewujudkan tata ruang sesuai dengan yang direncanakan, pihak swasta terpengaruhi dalam kaitanya pengajuan perijinan kegiatan usaha yang berkaitan dengan pemanfaatan harus sesuai dengan Rencana Tata Ruang dan wilayah, dan masyarakat terpengaruhi dalam kaitannya pengajuan ijin pemanfaatan ruang baik bersifat pribadi maupun kelompok.

\section{Manfaat Implementasi Pengendalian Pemanfaatan Ruang}

Berdasarkan informasi tersebut dapat ditarik kesimpulan bahwa hingga saat ini manfaat yang sudah diperoleh dengan adanya pengendalian pemanfaatan ruang adalah peningkatan Pendapatan Asli Daerah (PAD) yang dihasilkan dari pembayaran retribusi perijinan pemanfaatan ruang oleh masyarakat 
Jurnal Ilmiah Untuk Mewujudkan Masyarakat Madani ISSN 2355-309X

maupun swasta. Sedangkan manfaat kesesuaian antara rencana tata ruang dan wilayah terhadap pemanfaatan ruang belum berjalan dengan maksimal.

\section{Derajad Perubahan}

Berdasarkan hasil wawancara dengan informan derajad perubahan yang ada hingga saat ini tentang pengendalian pemanfaatan ruang di Kota Salatiga dapat dilihat dari beberapa aspek, yaitu aspek keindahan kota, aspek kualitas tanah dan aspek drainase. Aspek keindahan kota, dengan adanya pengendalian pemanfaatan ruang diharapkan terjadi perubahan dalam tatanan kota sehingga kota menjadi lebih indah, nyaman dan tertata. Aspek kualitas tanah, pengendalian dapat membatasi pembangunan atau pengalihfungsian lahan dimana pembangunan akan menghabiskan lahan yang berfungsi sebagai penyerap air sehingga dapat mempengaruhi kualitas air baik air tanah maupun air permukaan. Selain berpengaruh terhadap resapan air, aspek yang diharapkan lainnya adalah drainase. Pengendalian pemanfaatan ruang juga akan mempengaruhi drainase kota, dimana dengan adanya pengendalian pemanfaatan ruang akan mengendalikan pembangunan permukiman sehingga masyarakat dalam pembangunannya akan diarahkan sesuai dengan tata ruang dan diwajibkan untuk membangun sumur resapan. Hal tersebut berfungsi untuk mengendalikan jumlah limbah yang masuk ke drainase kota. Namun dalam kenyataannya menurut informan, pengendalian belum berjalan dengan maksimal sehingga perubahan yang diharapkan belum dapat dirasakan hingga saat ini. Hal ini disebabkan masih adanya keterbatasan Sumber Daya Manusia, keuangan dan dalam pelaksanaan pengendalian di lapangan masih terdapat pelanggaran-pelanggaran pemanfaatan ruang oleh masyarakat.

\section{Kedudukan pembuat kebijakan}

Badan Koordinasi Penataan Ruang
(BKPRD) dibentuk dengan tujuan
mempermudah walikota dalam menjalankan
penataan ruang. Anggota BKPRD terdiri dari seluruh instansi yang ada di Kota Salatiga, seluruh kecamatan dan kelurahan. BKPRD sendiri terbagi dalam dua program kerja, yaitu program kerja perencanaan dan program kerja pengendalian, dimana masing-masing program kerja memiliki penanggungjawab. Program kerja perencanaan merupakan tanggungjawab dari Kepala Bidang Sarana dan Prasana Tata Ruang Bappeda Kota Salatiga, sedangkan program kerja pengendalian menjadi tanggung jawab dari Kepala Bidang Tata Ruang dan Bangunan Dinas Ciptakaru Kota Salatiga. Pelaksanaan pengendalian sendiri terdiri dari dua kegiatan yaitu pengawasan dan penertiban, sehingga dalam pelaksanaanya juga memiiliki penanggungjawab yang berbeda. Pengendalian berbentuk kegiatan pengawasan menjadi tanggungjawab dari Dinas Ciptakaru selaku instasni pengampu, sedangkan pengendalian berbentuk kegiatan penertiban menjadi tanggungjawab dari Satuan Polisi Pamong Praja selaku instansi penegak peraturan daerah.

\section{Sumber daya manusia}

Berdasarkan hasil wawancara tersebut dapat disimpulkan bahwa dalam pelaksanaan di lapangan SDM baik Dinas Ciptakaru maupun Satuan Polisi Paong Praja baik secara kuantitas maupun kualitas masih sangat terbatas. Hal ini akan menyebabkan Implementasi berjalan tidak maksimal dan tidak dapat menghasilkan perubahan yang sesuai dengan yang telah direncanakan.

\section{Pelaksanaan Pengendalian}

Pelaksanaan kebijakan di lapangan merupakan faktor penting lainnya dalam proses implementasi, dimana kegiatan ini merupakan kegiatan utama dari adanya suatu kebijakan. Pembahasan pada bab pelaksanaan pengendalian terbagi dalam beberapa subbab yaitu instansi pelaksana, pengawasan dan penertiban. Berdasarkan informasi yang peneliti peroleh baik dari hasil wawancara maupun dokumen dapat disimpulkan sebagai berikut :

\section{Instansi Pelaksana}


Itianah Setyaningsih, Analisis Pengendalian Pemanfaatan Ruang Di Kota Salatiga...

Menurut informasi yang peneliti peroleh dari hasil wawancara dengan informan instansi pelaksana pengendalian terbagi dalam beberapa instansi yang berdasarkan pada pembagian dalam Forum BKPRD, dimana pengendalian pemanfaatan ruang dilaksanakan dalam dua bentuk kegiatan yaitu pengawasan dan penertiban. Instansi yang mengampu antara lain Dinas Ciptakaru, Satuan Polisi Pamong Praja, Badan Perijinan Terpadu dan beberapa instansi yang menjadi anggota BKPRD.

\section{Pembagian Tugas}

Pembagian tugas dari masing-masing instansi pelaksana dilakukan berdasarkan tanggungjawabnya dalam keanggotaan BKPRD. Dinas Ciptakaru memiliki tugas kaitannya dalam pengendalian berbentuk pengawasan, dimana pengawasan terdiri dari beberapa kegiatan antara lain kegiatan pelaporan pra pembangunan dan pasca pembangunan, pemantauan, dan evaluasi. Sedangkan Satuan Polisi Pamong Praja memiliki tugas dalam pengendalian yang berbentuk kegiatan penertiban. Selain dari dua instansi utama, ada beberapa instansi yang turut serta dilibatkan dalam pelaksanaan pengendalian, antara lain Badan Pertanahan dimana Dinas Ciptakaru akan melakukan koordinasi dengan BPN apabila pengendalian pemanfaatan ruang dilaksanakan dan berkaitan dengan badana pertanian. Tugas BPN dalam hal ini adalah pemberian ijin pengalihfungsian lahan pertanian menjadi lahan permukiman. Selain itu Dinas Ciptakaru juga melakukan koordinasi dengan Dinas Perhubungan apabila pengendalian berkaitan dengan pemanfaatan jaringan jalan.

\section{Pengambil keputusan}

Pengambil keputusan tertinggi dalam setiap tindakan pengendalian pemanfaatan ruang adalah walikota Salatiga, yang kemudian akan dilimpahkan kewenangannya kepada instansi pelaksana melalui forum BKPRD. Pengendalian dalam bentuk kegiatan pengawasan merupakan tanggungjawab dari Dinas Ciptakaru, dimana dinas Ciptakaru menjadi pengambil keputusan dalam pemberian ijin kepada masyarakat yang mengajukan ijin pemanfaatan ruang. Dinas Ciptakaru mengeluarkan ijin berkaitan dengan pertimbangan teknis tentang pembangunan sesuai dengan rencana tata ruang ataukah tidak, sedangkan Satuan Polisi Pamong Praja bertanggungjawab dalam pengambilan keputusan yang berkaitan dengan penertiban apabila ditemukan pelanggaran pemanfaatan ruang setelh adanya surat pemberitahuan dari Dinas Ciptakaru.

\section{Koordinasi Tugas}

Berdasarkan hasil penelitian dapat diketahui bahwa koordinasi antara anggota pokja pengendalian dalam forum BKPRD belum berjalan dengan maksimal. Padahal koordinasi antar anggota sangat dibutuhkan agar pengendalian dapat berjalan sesuai dengan tujuan pengendalian yaitu menciptakan kesesuaian antara rencana dengan pemanfaatan ruang.

\section{Pengawasan}

Berdasarkan hasil penelitian, kegiatan pemantauan yang dilakukan oleh Dinas Ciptakaru Kota Salatiga hingga saat ini dilakukan setelah memperoleh pelaporan dari wajib lapor maupun hak lapor. Pelaporan dari wajib lapor berupa perijinan pemanfaatan ruang yang setelah masuk ke Dinas Ciptakaru maka selanjutnya Dinas Ciptakaru melaksanakan peninjauan di lapangan berkaitan dengan lahan yang akan dimanfaatkan apakah sesuai dengan ketentuan tata ruang atau tidak. Apabila setelah pemantauan ternyata lokasi tidak sesuai dengan tata ruang maka ijin tidak akan diberikan, jika sesuai dengan tata ruang ijin akan dikeluarkan. Ijin dikeluarkan dengan beberapa syarat diantaranya tentang tinggi bangunan yang diijinkan, dan aturan teknis tentang pembangunan. Pengawasan pasca pembangunan tetap dilakukan oleh Dinas Ciptakaru meskipun tidak adanya pelaporan dari masyarakat.

\section{Penertiban}

Pengendalian pemanfaatan ruang berupa kegiatan penertiban di Kota Salatiga dilaksanakan oleh Satuan Polisi Pamong Praja, dimana penertiban dilaksanakan setelah 
ditemukan adanya pelanggaran pemanfaatan ruang dari masyarakat.

Berdasarkan hasil penelitian diperoleh informasi bahwa pelaksanaan penertiban di Kota Salatiga oleh Satuan Polisi Pamong Praja Kota dilakukan tidak hanya untuk mengendalikan bangunan-bangunan namun juga mengendalikan pemasangan reklamereklame di jalan. Kegiatan penertiban oleh Satpol PP kota Salatiga dilakukan dengan melalui dua pendekatan yaitu yustisi dan non yustisi. Pendekatan yustisi dilakukan dengan tindakan pembongkaran secara langsung di tempat kejadian atau memberikan sanksi kepada pelanggar. Pendekatan non yustisi dilakukan dengan cara memberikan pengarahan dan sosialisi tentang peraturan pemanfaatan ruang yang berlaku. Maka dapat ditarik kesimpulan bahwa pengendalian dalam bentuk kegiatan penertiban berjalan sesuai dengan tahapan yang ada, dimana Satpol PP akan melakukan tindakan penertiban dengan memberikan sanksi administratif, perdata ataupun pidana. Hal tersebut sesuai dengan yang tercantum dalam Perda No 4 Tahun 2011 pasal 74

\section{Konteks Kebijakan Pengendalian Pemanfaatan Ruang}

\section{Faktor Internal}

\section{Tingkat Kepatuhan dan daya tanggap}

Berdasarkan hasil penelitian, peneliti menemukan bahwa tingkat kepatauhan dalam implementasi pengendalian dapat dilihat dari sisi instansi pelaksana dan masyarakat. Dari sisi instansi pelaksana, tingkat kepatuhan dilihat dari adanya koordinasi antara instansi pelaksana pengendalian pemanfaatan ruang dalam memberikan ijin kepada masyarakat yang akan melakukan pemanfaatan ruang. Dari sisi masyarakat, tingkat kepatuhan masyarakat dalam implementasi pengendalian pemanfaatan runag dapat dilihat melalui volume pengajuan ijin pemanfaatan ruang yang masuk ke Dinas Ciptakaru Kota Salatiga, Kantor Perijinan Terpadu. Berdasarkan hasil penelitian tersebut maka dapat disimpulkan bawha tingkat kepatuhan dan daya tanggap masyarakat ataupun instansi pelaksana dalam implementasi pengendalian pemanfaatan ruang sudah cukup baik

\section{Sosialisasi}

Sosialisasi yang dilaksanakan oleh

Dinas Ciptakaru berkoordinasi dengan kelurahan, kecamatan, Bappeda Kota, Kantor Pertanahan dan SKPD lain yang terkait dengan pengendalian pemanfaatan ruang. Sosialisasi dilakukan apabila ada peraturan baru yang disahkan oleh Pemerintah Kota Salatiga dan salah satunya adalah Perda No 4 Tahun 2011 tentang Rencana Tata Ruang dan Wilayah. Namun dalam kenyataannya sosialisaii yang dilakukan oleh Dinas Ciptakaru belum mampu mencapai masyarakat tingkat bawah. Hal ini disebabkan sosialisasi hanya dilakukan pada tingkat kecamatan sedangkan tingkat bawah seperti RT/RW tidak pernah memperoleh sosialisasi.

\section{Faktor Eksternal}

\section{Faktor Politik}

Berdasarkan keterangan yang peneliti peroleh dari wawancara dengan informan, pada pelaksanaan pengendalian pemanfaatan ruang terdapat dukungan yang cukup baik dari pemerintah. Dukungan tersebut berupa pengesahan anggaran yang diajukan oleh Satpol PP dan Dinas Ciptakaru oleh DPRD Kota Salatiga. Namun dalam anggaran yang diberikan kepada Dinas Ciptakaru masih terbatas, terutama untuk pelaksanaan kegiatan monitoring dan evaluasi. Selain adanya anggaran yang disediakan dukungan politik juga diberikan dengan disusunya rencana detail tata ruang yang mengatur secara rinci instrumen-instrumen yang mengatur tentang pengendalian pemanfaatan ruang.

\section{Masyarakat}

Dalam pelaksanaan di lapangan tidak semua masyarakat mengetahui adanya pengendalian pemanfaatan ruang atau bahkan tidak mengetahui adanya peraturan tata ruang. Hal ini disebabkan karena kurang adanya sosialisasi dari instansi pelaksana dan juga karena kurangnya kesadaran masyarakat untuk menjaga lingkungan sekitarnya. 
Itianah Setyaningsih, Analisis Pengendalian Pemanfaatan Ruang Di Kota Salatiga...

Berdasarkan hasil analisis overlay peta diatas maka dapat disimpulkan bahwa pemanfaatan ruang di Kota Salatiga masih belum sesuai dengan rencana tata ruang yang di buat oleh pemerintah. Sehingga pengendalian pemanfaatan ruang harus dilaksanakan dengan semsestinya untuk mengembalikan fungsi-fungsi ruang yang dimanfaatkan tetaoi tidak sesuai dengan peruntukkannya. Melihat dari hasil analisis overlay diatas, menunjukkan masih banyak wilayah-wilayah di Kota Salatiga yang dibangun tanpa mengikuti rencana tata ruang dan wilayah.

\section{KESIMPULAN}

a. Implementasi pengendalian pemanfaatan ruang di Kota Salaiga kurang berhasil dilaksanakan disebabkan kegiatan pengendalian yang berupa pengawasan belum dilaksanakan sesuai dengan peraturan yang ada, masih ada tahapan yang belum terlaksana seperti tahapan pelaporan saat pembangunan dan pasca pembangunan serta evaluasi pelaksanaan pembangunan belum dapt dilaksanakan.

b. Penelitian ini dimaksudkan untuk menganalisis konten kebijakan dan konteks kebijakan. Berikut hasil analisis taksonomi dari berbagai faktor tersebut :

1) Konten kebijakan pengendalian pemanfaatan ruang Kota Salatiga

a) Kepentingan yang terpengaruhi

Kepentingan yang terpengaruhi dalam implementasi pengendalian adalah masyarakat, pemerintah dan swasta. Masing-masing terpengaruhi dalam sisi pelaksanaan dan pengajuan ijin pemanfaatan ruang.

b) Manfaat implemantasi Pengendalian pemanfaatan ruang

Implementasi pengendalian pemanfaatan ruang dalam pelaksanaannya telah memberikan manfaat peningkatan Pendapatan Asli Daerah. Namun dalam sisi penataan ruang belum memberikan hasil yang maksimal.

c) Derajad perubahan

Perubahan yang diinginkan dengan adanya pengendalian pemanfaatan ruang adalah menciptakan kota yang tertata dengan indah, menjaga kualitas tanah dan keberadaan drainase kota. Namun perubahan yang diharapkan belum terlaksana dengan maksimal karena adanya keterbatasan keuangan dan SDM.

d) Kedudukan pembuat kebijakan

Kebijakan yang dilaksanakan dalam pengendalian menjadi tanggungjawab dari Walikota Salatiga sebagai pemegang kekuasaan tertinggi. Namun dalam pelaksanaannya di bentuk wadah Badan Penataan Ruan Daerah, yang terbagi dalam pokja rencana dan pokja pengendalian. Pokja rencana menjadi tanggungjawab Bappeda Kota Salatiga, pokja pengendalian menjadi tanggungjawab Dinas Ciptakaru.

e) Sumberdaya Manusia

Sumber daya mannusia yang menjadi pelaksana dari instansi terkait jumlahnya masih sangat terbatas baik secara kuantitas maupun kualitas, sehingga pelaksanaan pengendalian berjalan kurang maksimal.

f) Pelaksana pengendalian

Pelaksanaan pengendalian dilakukan oleh dua instansi berbeda sesuai dengan jenis pengendalianya. Pengendalian dengan kegiatan pengawasan dilaksanakan oleh Dinas Ciptakaru, dan pengendalian dnegan kegiatan penertiban dilaksanakan oleh Satpol PP. Pembagian tugas dari masing-masing instansi diatur berdasarkan tanggungjawabnya di keanggotaan BKPRD. Pengambil keputusan tertinggi ada pada Walikota, sedangkan untuk pelaksanaan di lapangan sesuai dengan tanggungjawab masing-masing kepala bidang instansi yang bertanggungjawab. Koordinasi tugas dilaksanakan melalui forum BKPRD setiap 3 bulan sekali, namun pelaksanaan koordinasi tidak berjalan dengan maksimal.

2) Konteks Kebijakan pengendalian pemanfaatan ruang

1) Faktor Internal

a. Tingkat kepatuhan dan daya tanggap

Kepatuhan dari masyarakat dan instansi pelaksana dalam pelaksanaan 
pengendalian pemanfaatan ruang cukup baik. Hal ini terlihat adanya koordinasi yang terjalin antar instansi dalam pemberian ijin kepada masyarakat. Kepatuhan masyarakat terlihat dari menigkatbnya oengajuan ijin ke Dinas Ciptakaru dan KPPT.

b. Sosialisasi

Sosialisasi dilakukan oleh pemerintah untuk memberikan informasi dan pemahaman kepada masyarakat tentang pemanfaatan ruang dan pengendalian pemanfaatan ruang, namun dalam pelasksanaannya tidak mencapai hingga masyarakat tingkat bawah. Sehingga masyarakat kurang memahami peraturan tentang pengendalian yang berlaku.

2) Faktor eksternal

a. Faktor politik

Terdapat dukungan secara politik dari pemerintah dalam pelaksanaan pengendalian yaitu memberikan dukungan berupa anggaran serta peraturan turuan yang menjelaskan dengan lebih detail tentang pengendalian. Namun untuk dukungan dalam bentuk anggaran masih ada keterbatasan karena belum semua kegiatan pengendalian mendapatkan anggaran yang cukup.

b. Masyarakat

Masyarakat menjadi andil penting dalam pelaksanaan, dimana partispasi masyarakat dapat dilakukan dengan melakukan kegiatan pelaporan apabila menemukan pelanggaran pemanfaatan ruang. Namun tidak semua masyarakat mengetahui dan memahami tentang adanya pengendalian pemanfaatan ruang.

\section{SARAN}

Saran pada penulisan ini memuat rekomendasi yang akan diberikan kepada Pemerintah Kota Salatiga agar dapat digunakan untuk memecahkan masalah penelitian. Berdasarkan simpulan yang di paparkan, dapat dikemukakan saran-saran sebagai berikut :

1. Berdasarkan hasil penelitian secara umum Implementasi Pengendalian Pemanfaatan
Ruang di Kota Salatiga belum dilaksanakan secara maksimal. Hal ini terlihat saat pelaporan pada tahapan awal sudah berjalan dengan baik dan perlu dipertahankan, sedangkan pelaporan pada tahapan akhir kegiatan pembangunan harus ditingkatkan dengan cara menetapkan kewajiban pelaporan saat pembangunan dan pasca pembangunan. Penggenaan sanksi pencabutan perijinan apabila tidak melakukan pelaporan saat pembangunan dan pasca pembangunan dapat memaksimalkan pengendalian pemanfaatan ruang.

2. Manfaat pengendalian yang belum dapat terlaksana dengan maksimal dapat ditingkatkan dengan cara mengikutsertakan masyarakat lapisan bawah selama proses pengendalian pemanfaatan ruang baik saat pengawasan pra pembangunan, pembangunan maupun pasca pembangunan dan saat penertiban.

3. Keterbatasan Sumberdaya Manusia pelaksana pengendalian dapat diatasi dengan melibatkan masyarakat dari tingkat kelurahan, RW hingga RT dalam proses pengendalian, dengan cara memberikan kewenangan secara sah kepada RW apabila menemukan pelanggaran di wilayahnya.

4. Meningkatkan sosialisasi yang diberikan tidak hanya dilaksanakan di kecamatan tetapi juga hingga masyarakat lapisan bawah, karena justru masyarakat lapisan bawah yang memiliki peran besar dalam pengendalian pemanfaatan ruang.

5. Anggaran khusus untuk pengendalian perlu ditingkatkan, mengingat cakupan pengendalian yang cukup luas mulai dari pengawasan hingga pelaporan.

6. Koordinasi antar instansi yang belum berjalan dengan baik dapat dilakukan dengan meningkatkan koordinasi yang biasanya dilakukan dalma waktu 3 bulan seklai menjadi 1 bulan sekali. Serta mewajibkan semua instansi yang menjadi anggota BKPRD untuk datang dalam koordinasi tersebut.

7. Menjalin kerjasama dengan pihak swasta ataupun perguruan tinggi yang ada di 
Itianah Setyaningsih, Analisis Pengendalian Pemanfaatan Ruang Di Kota Salatiga...

Kota Salatiga guna meningkatkan partisipasi masyarakat dalam memperhatikan lingkungan sekitarnya dengan mengadakan seminar atau workshop.

8. Meningkatkan peran serta masyarakat dalam pengendalian pemanfaatan ruang dengan cara memberikan nomor pengaduan yang mudah dihubungi oleh masyarakat guna melaporkan pembangunan yang menyalahi aturan,

\section{DAFTAR PUSTAKA}

Adisasmita, Rahardjo.(2010). Pembangunan Kota Optimum dan Efisien \& Mandiri. Yogyakarta: Graha Ilmu (2010). Pembangunan Kawasan dan Tata Ruang. Yogyakarta: Graha Ilmu

Afifuddin.(2009). Metodologi Penelitian Kualitatif. Bandung : CV Pustaka Setia

Badjuri, Abdulkahar dan Teguh Yuwono. (2002).Kebijakan Publik Konsep dan strategi. Semarang: Universitas Diponegoro

Budihardjo, Eko.(1997). Tata Ruang Perkotaan. Bandung: Penerbit PT Alumni

Djakapermana, Ruchyat Deni.(2010).Pengembangan Wilayah Melalui Pendekatan Kesisteman.Bogor: Penerbit IPB Press

Hadi, Sudharto P.(2005).Dimensi Lingkungan Perencanaan

Pembangunan.Yogyakarta: Gadjah Mada University Press

Keban.T Yeremias.(2004). Enam Dimensi Strategis Administrasi Publik. Yogyakarta: Gava Media.

Mantra, Ida Bagoes. (2004).Filsafat Penelitian dan Metode Peneltian Sosial. Yogyakarta: Pustaka Pelajar

Nugroho, Riant.(2008).Public Policy.Jakarta: PT.Elex Media Komputindo

Owen E. Hughes.( 1994). Publik Management and Administration; and Introduction Owen E. Hughes. New York : Scholarly and Reference division, ST. MARTIN'S PRESS, INC.
Rustiadi, Ernan. Sunsun Saefulhakim dan Dyah R. Panuju. (2009).Perencanaan Pengembangan Wilayah.Jakarta: Yayasan Obor Indonesia

Sadyohutomo, Mulyono.(2009). Manajemen

Kota dan Wilayah Realita dan

Tantangan. Yakarta: Bumi Aksara

Sugiyono.2012.Memahami Penelitian Kualitatif.Bandung :CV. Alfabeta

Supriyanto, Budi.(2009).Manajemen Tata Ruang.Tangerang:CV.Media Brilian

Thoha, Miftah.(2008). Ilmu Administrasi Publik Kontemporer.Jakarta: Prenada Media Group

Tjokroamidjojo, Bintoro.(1977).Perencanaan Pembangunan.Jakarta: PT. Gunung Agung

Trisnawati Sule, Ernie dan Kurniawan Saefullah.(2005). Pengantar Manajemen.Jakarta : Prenada Media Group

Tesis

Prima Hayuningtyas, Andita,2013.Evaluasi Kebijakan Pengangkatan PNS dalam Jabatan Struktural di KabupatenPurbalingga.Tesis Studi Magister Administrasi Publik Pasca Sarjana Undip.Semarang

Senobua, Nicolaus,2001. Efektivitas Pengendalian Pemanfaatan Ruang Kota: Kasus Kota Ponorogo,Tesis Program Studi Perencanaan Kota dan Daerah-Program Pasca Sarjana UGM, Yogyakarta.

Srianto, Yusman,2001. Pengendalian Pemanfaatan Ruang melalui Instrumen Ijin Mendirikan Bangunan (IMB): Studi kasus di Kota Ungaran, Tesis Program Studi Magister Perencanaan Kota dan DaerahProgram Pasca Sarjana Universitas Gajah Mada, Yogyakarta.

Saputro, Tri Hendrasmana, 2012. Kajian Implementasi Peraturan dalam Rangka Pengendalian Pemanfaatan Ruang, Kasus Kawasan Padat di Jakarta, Tesis Program Studi Magister Perencanaan Kota dan Daerah Program Pasca Sarjana UGM, Yogyakarta. 
Jurnal Ilmiah Untuk Mewujudkan Masyarakat Madani

ISSN 2355-309X

\section{Jurnal dan Artikel}

Ahmad, Haris. 2011. Teknik Analisis Overlay . ( http://harisahmad.blogspot.com, diunduh 12 Febuari 2013)

Departemen Pekerjaan Umum, Pedoman Pengendalian Pemanfaatan Ruang di Kawasan Perkotaan, (http://www.pu.go.id, diakses $10 \mathrm{mei}$ 2013)

Profil Kota Salatiga.(2011). Dalam http:/www./pemkot-salatiga.go.id//. Diunduh pada tanggal 26 September pukul 17.00 WIB

Rahman, Arif Hakim. 2011.Apa Itu Manajemen Publik. (http://arifrahmanarsv, diakses pada 26 April 2013)

Peraturan Perundang-undangan

Peraturan Daerah Kota Salatiga Nomor 4 Tahun 2012 Tentang Rencana Tata Ruang dan Wilayah Kota Salatiga

Undang-Undang No 26 Tahun 2007 tentang Penataan Ruang

Website

http://www.penataanruang.com/pengendalianpemanfaatan-ruang.html diakses 10 Mei 2013 